\begin{tabular}{|l|l|}
\hline $\begin{array}{l}\text { Postprint } \\
\text { Version }\end{array}$ & 1.0 \\
\hline Journal website & $\underline{\mathrm{http} / / \mathrm{www} 3 . \text { interscience.wiley.com/journal/122540952/abstract }}$ \\
\hline Pubmed link & $\underline{\mathrm{http} / / \mathrm{www} \text {.ncbi.nlm.nih.gov/pubmed/10564410 }}$ \\
\hline DOI & $10.1111 / \mathrm{j} .1365-2648.2009 .05051 . \mathrm{x}$ \\
\hline
\end{tabular}

This is a NIVEL certified Post Print, more info at http://www.nivel.eu

\title{
Factors related to nurse communication with elderly people
}

\author{
WILMA M.C.M. CARIS-VERHALLEN MSC RN ${ }^{1}$, INGRID M. DE GRUIJTER MA ${ }^{2}$, ADA \\ KERKSTRA PHD ${ }^{3}$ AND JOZIEN M. BENSING PHD ${ }^{4}$ \\ ${ }^{1}$ Research Fellow, Department of Nursing and Caring Research, Netherlands Institute of \\ Primary Health Care \\ ${ }^{2}$ Research Assistant, Department of Nursing and Caring Research, Netherlands Institute of \\ Primary Health Care \\ ${ }^{3}$ Co-ordinator, Department of Nursing and Caring Research, Netherlands Institute of Primary \\ Health Care \\ ${ }^{4}$ Director, Netherlands Institute of Primary Health Care, Utrecht, and Department of Clinical \\ and Health Psychology, University of Utrecht, Utrecht
}

This study explores variables that might influence nurses' communication with elderly patients. Three groups of variables arise from the literature that seem to affect the quality or quantity of nurse-patient communication: variables related to nurses, to patients, and to the setting in which nursing care takes place. The study was conducted in two different care settings: a home for elderly people and a home care organization. In a sample of 181 video-taped nursing encounters, involving 47 nurses and 109 patients a study was made of nursepatient communication. In addition, relevant data related to patients, nurses and situation were gathered by questionnaires and were combined with the results of observations of videotaped nurse-patient interactions. It was found that the educational level of nurses was related most strongly to the way nurses communicate with their elderly patients. Patient characteristics such as age, gender and subjective state of health appeared to play a minor role in the way nurses communicate.

\section{INTRODUCTION}

Communication with patients has been recognized as one of the most important aspects of nursing elderly people (Hockey 1976, Armstrong-Esther et al. 1989, Van Cott 1993). Furthermore, communication is an important aspect of the quality of care. From several studies it appears that poor communication is the largest source of dissatisfaction in patients (Macleod Clark 1985, Ley 1988, Davies \& Fallowfield 1991). Consequently, the quality of care may improve with effective communication. Effective communication does not just depend on the acquisition of the right communication skills (Wilkinson 1991). In the literature, three groups of variables have been identified that seem to determine the quality or quantity of nurse-patient communication: variables related to nurses (referred to in this 
article as provider variables), variables related to patients and variables related to the situation, in particular ward characteristics (Caris-Verhallen et al. 1997a). In this paper, these three groups of variables are related to the way nurses communicate in practice with elderly people.

\section{Provider variables}

In several studies it has been suggested that nurses' approach to and treatment of elderly people is mainly determined by a negative predisposition towards elderly patients and a tendency to stereotype them as having undesirable traits and characteristics (Taft 1985, Brasker \& Visser 1990, Treharne 1990, Penninx 1995). Armstrong- Esther et al. (1989) showed that nurses in different grades, with a favourable attitude towards elderly people, attached value to conversations with their older patients, while nurses with a less favourable attitude thought it was more important to deliver physical, hygienic care. In contrast, Salmon (1993) was not able to demonstrate a relationship between nurses' attitude towards older people and their communicative behaviour. He found that establishing formal interaction periods led to a greater increase in interactions than targeting nurses' attitudes. One positive factor relating to communication might be the amount of nurses' job satisfaction. Wilkinson (1991) reported that nurses used more facilitating than blocking communication, when they were satisfied with the general atmosphere on the ward. Kramer \& Kerkstra (1991) showed that nurses with high levels of intrinsic job motivation and satisfaction with colleagues were more sensitive to elderly patients' needs than nurses with lower levels of these job satisfaction aspects. The amount of training and the educational level of nurses are other characteristics that have been shown to have an in ${ }^{-}$uence on nurses' communication. Davies (1992) found that although trained and untrained staff used broadly the same range of verbal strategies, trained staff used proportionately more of those strategies that promoted patients' dignity, self-respect, choice and independence. Moreover, unqualified nurses were less sensitive to underlying meanings in verbal communication of elderly clients. Liefbroer \& Visser (1986) asserted that nurses with a higher level of education use more patientdirected statements than nurses with a lower level of education. High level nurses for instance provide the patient with more information about sickness and health than lower level nurses. Burgener \& Shimer (1993) demonstrated that the total number of years of education was related to a number of communication categories, such as paying attention, giving comfort and the use of feedback behaviours. These authors also showed that there was a relationship between the amount of nursing experience with cognitively impaired patients and nurses' non-verbal behaviour, smiling in particular. The relationship between demographic factors and nurse communication has been examined in several studies (Pool 1983, Liefbroer \& Visser 1986, Wilkinson 1991, Burgener \& Shimer 1993). It is not clear whether characteristics such as age, gender and years of employment are related to the quality and quantity of communication. The results of existing studies are contradictory (Caris-Verhallen et al. 1997a).

\section{Patient characteristics}

Patient characteristics that have been shown to have an in ${ }^{-}$uence on nurse communication are gender, age and health. Lane (1989) studied 80 registered nurses in an outpatient setting and found that they were less likely to touch a male patient than a female patient. Visser (1988) reported that hospitalized elderly people were kept less informed about medical topics than younger people. Concerning health, Allen \& Turner (1991) suggested in a study that nurses might be less likely to interact with physically dependent patients than the more physically able. They referred to the Armstrong-Esther \& Browne study (1986), which produced a comparable conclusion for mentally impaired patients: nurses interacted significantly less with confused elderly patients than with their alert patients. de Wilde \& de Bot (1989) described nurses as using the characteristics of baby talk with patients showing signs of dementia. 


\section{Situational variables}

Ward characteristics have in several studies been shown to have an effect on nurse-patient interaction. Gibb \& O'Brien (1990) showed that nurses who were responsible for the ward during morning care and experienced pressure of time, were brief and task-related in interaction with their patients. They used mostly closed rather than open questions, and did not negotiate about the care delivered. Yet, pressure of time does not always in ${ }^{-}$uence nurses' communication negatively. Wilkinson (1991), for instance, compared nurses on six different wards in a general hospital and found that the ward where the best communication took place was very busy. Additionally, the nursing organization method is a setting variable of in uence. Thomas (1994) showed that nurses on primary care wards (a patient is allocated to a nurse, who has responsibility for patient's total care) used different verbal strategies than nurses who worked on wards using team and functional nursing. In that study team nursing was defined as patient allocation to a small team of responsible nurses and functional nursing was a way of organizing nurses' work divided into separate tasks (Thomas \& Bond 1990, Thomas 1994). In other studies, it appeared that on wards where special activity programmes were arranged, there was a positive in uence on the amount of nurse-patient interaction (Salmon 1993, Turner 1993).

\section{Research questions}

As a part of a larger study into nurse-elderly patient communication (Caris-Verhallen et al. 1997b), the aim of this research was to investigate how characteristics of nurses, patients and situation relate to nurse-patient communication. Three research questions guided this report:

1. To what extent are provider variables, such as educational level, nursing experience, attitude, job satisfaction, age and gender, related to the way nurses communicate with their patients?

2. To what extent are patient variables, such as age, gender, subjective health and duration of received care, related to the way nurses communicate with their patients?

3. To what extent are situational variables, such as pressure of time and the number of patients in a shift, related to the way nurses communicate with their patients?

It was hypothesized that nurses with a positive attitude towards elderly patients, would pay more attention to social conversation in nursing. Because nurses with a higher level of satisfaction were shown to be more sensitive to patients' underlying problems, it was expected that they would pay more attention to psychosocial items and use more affective communication, which is necessary to create and maintain a relationship with their patients. Further, we hypothesized that nurses with a higher educational level would use more patientdirected communication strategies, including providing information about nursing and health, than lower level nurses. Based on previous research there were no expectations with respect to nurses' age, gender and work experience. With respect to patient variables we expected that nurses communicate less about nursing and health with older patients than with younger ones. It was also assumed that male patients were less often touched by nurses than female patients. On the basis of the research cited above it was not possible to express expectations concerning the relationship between patient health and nurse communication, because study designs and settings were not comparable. With respect to the situational factors, it was assumed that nurses who have little work pressure would concentrate on creating and maintaining a relationship with their patients. They will more often employ social conversation and affective behaviour than nurses under pressure of work. 
Caris-Verhallen, W.M.C.M., Gruijter, I.M. de, Kerkstra, A., Bensing, J.M. Factors related to nurse communication with elderly people. Journal of Advanced Nursing: 1999, 30(5), p. 1106-1117

\section{METHODS}

\section{Subjects}

Forty-seven nurses took part in the study. They all were participants in a larger project, in which training in communication skills was given and evaluated, using a pre-test post-test design. This paper reports on the pre-test. Twenty-four nurses worked in a home care organization and provided nursing care in the community. Twentythree nurses provided care in a home for elderly people. The nurses had completed initial nursing training at two levels, their mean age was 39 years. On average, they had about 16 years experience as a nurse (Table 1). One hundred and nine patients agreed to participate in the study. Eighty-one patients lived in the community, their mean age was 77.5 years. Most of the patients in home care received nursing care for a long period (mean 37 months). Twenty-eight patients were residents of an old people's home. These residents were older than the patients in the community. Their mean age was 86.7 years. On average, they lived about five and a half years in the institution (Table 2).

\section{[TABLE 1]}

\section{[TABLE 2]}

\section{Data collection}

In order to meet the research objectives, several methods were used for data collection. At the start of the project, all participating nurses were asked to complete questionnaires on provider characteristics. Then, to describe nurse-patient communication, 181 real nursepatient interactions were videotaped, during the delivery of nursing care. A supervised camera was used, with the focus on the interaction, except during nursing activities where the patient was undressed. In these cases the video camera focused on the nurse, or where that was impossible only verbal communication was recorded. Nurses recruited the patients for this study. A few days prior to the data collection, nurses informed their patients about the research, and they asked them to give informed written consent to participation. Only a negligible minority of patients refused permission. Very sick patients, patients suffering from dementia and terminally ill patients were excluded from participation. The video recordings, which were later systematically observed and analysed by the researchers, yielded data about the nurse-patient interaction. In addition, patients informed the researchers about demographic characteristics and health, during a short interview, after each video-taped encounter, while nurses completed a questionnaire on situation variables.

\section{The observation scheme}

The observation scheme consisted of three parts: verbal communication, non-verbal communication and the atmosphere during the nursing encounter. The latter was assessed with global affect ratings.

\section{Verbal communication}

Verbal communication was observed using the adapted version of Roter's Interaction Analysis System (RIAS) (Roter 1989). This scheme uses verbal utterances as a unit of analysis. Each utterance, which is defined as the smallest distinguishable speech segment to which a coder can assign a classification, was allocated to one of 24 categories. In earlier research these 24 categories were clustered into five clusters of more general communication behaviours (Caris-Verhallen et al. 1998). These include:

1. Social communication, providing information about the degree to which the nurse uses social conversation that has no particular function in nursing activities such as personal statements, small talk and banter. 
2. Affective communication, involves utterances that express verbal attentiveness, concern and empathy with the patient.

3. Communication that structures the encounter, involves utterances that indicate guidance and direction such as orienting and instructing, requests for clarification, asking for understanding and asking for opinion.

4. Communication about nursing and health, containing all items with respect to nursing, health, medical or therapeutic topics.

5. Communication about lifestyle and feelings, containing all items with respect to lifestyle and emotions. In this study for each of the five verbal behaviours summary statistics were calculated, representing the proportion of total amount of utterances nurses spent within one of the five types of verbal communication.

\section{Non-verbal communication}

The observation scheme contained five non-verbal categories that are important to establish a good relationship with the patient (Heintzman et al. 1993): patient directed gaze, affirmative head nods, smiling, forward leaning and touch. Because touch is inherent in nursing activities, during observation a distinction was made between instrumental touch, which is necessary to perform a task, and affective touch which expresses affection. Only the latter is important for rapport building. For the non-verbal categories, the duration was recorded. Proportional scores were used. The variables 'eye gaze direction', 'forward leaning', 'affective touch' and 'instrumental touch' were divided by the duration of time that nurse and patient were in sight. Similarly the 'head nodding' and 'smiling' variables were adjusted by dividing duration by the time that the nurse's head was in sight (Caris-Verhallen et al. 1997b).

\section{Global affect ratings}

In addition to the observation of non-verbal and verbal communication, as described above, the general impression of nurse's communication was rated by two observers on seven 6-point rating scales, measuring irritation, nervousness, assertiveness, interest, warmth, patronizing/ unequal attitude and involvement ( $1=$ low, $6=$ high) (Roter 1989, CarisVerhallen et al. 1997b).

\section{Observations}

All 181 video records were systematically observed by two observers using the CAMERA computer system (Iec ProGAMMA 1994), which is designed for coding behavioural interactions from video recordings. Based on the results of a preliminary study (CarisVerhallen et al. 1998) the observation time was standardized and the first 10 minutes were observed of each nursing encounter. Ten of the encounters were coded by each of the two observers in order to calculate the inter-rater reliability. Cohen's Kappa of the verbal categories varied between 0.74 and 0.81 , and Pearson's $r$ of the non-verbal categories and global affect ratings proved to between 0.69 and 0.98 Pearson's $r$.

\section{Measurement of related factors}

\section{Provider variables}

Nurses' attitude towards elderly people was measured using Kogan's Old People Scale (KOP scale) (Kogan 1961). Although this instrument is 35 years old, it is still used in many 
studies (Smith 1982, Brown et al. 1992, Armstrong-Esther et al. 1994, Hope 1994, Lookinland \& Anson 1995), which report a good level of reliability. The original version of the KOP scale presents 17 positively and 17 negatively formulated statements, with a 5-point response format (strongly agree, agree, don't know, disagree and strongly disagree). Usually these items are disguised in long questionnaires between other items, so it is not too obvious that two opposites of the same questions are being asked. This was not possible in our study. Accordingly, opposite questions were presented in pairs, and respondents were asked how much they agreed with the statements. The internal consistency of this adapted instrument was acceptable (Cronbach's alpha 0.72). Nurses' tendency towards therapeutic behaviour was measured with the therapeutic behaviour scale, constructed and examined for validity and reliability by Pool (1983). This is a 26-item scale, by which nurses have to assess the amount and quality of the provision of information, emotional support and promotion of autonomy. The respondents had to rate how often they carried out a particular intervention on a 5-point scale ( $5=$ very often, $1=$ never). Because some of the items were not characteristic for nursing, the original 26 -item scale was adapted to a 23 -item instrument. The internal consistency for the questionnaire was 0.87 (Cronbach's alpha). Based on the literature, two satisfaction outcomes were measured, which are derived from the satisfaction questionnaire from Boumans et al. (1989). 'Satisfaction with work intrinsic aspects' is a 7-item scale, with items such as: 'For me, my job is significant' (5-point scale, $1=$ very dissatisfied, $5=$ =very satisfied). The internal consistency was $0 \cdot 84$ (Cronbach's alpha). The 'satisfaction with peer contacts' scale comprises six items (Cronbach's alpha $=0.85$ ) and measures how satisfied nurses are with social contacts with colleagues, e.g. 'To what degree are you satisfied having good friends among your colleagues?' (5- point scale, 1=very dissatisfied, 5=very satisfied). Several individual characteristics were measured like education, amount of nursing experience and demographic characteristics.

\section{Patient characteristics}

Age, gender and duration of nursing care were registered for all participating patients. Subjective health was measured on a 5-item scale, which formed part of an instrument measuring elderly peoples' well-being (Tempelman 1987). The internal consistency of this scale was 0.84 (Cronbach's alpha).

\section{Situational variables}

To measure the amount of time pressure, a 5-item scale was used (Ruijters \& Stevens 1992) indicating how nurses judge the amount of time they are able to spend to direct patient care (5-point scale, $1=$ enough time, $5=$ too little time, Cronbach's alpha $=0.77$ ). The amount of workload was determined by asking the number of working hours a week and the number of nursing encounters during a shift.

\section{Analyses}

In order to investigate whether nurse, patient or situational characteristics were related to the way nurses communicated with their patients, correlational techniques were used. The strength of the relations was expressed as Pearson's $r$. Prior to the correlational analyses, we tested differences between the two settings concerning patients, nurses and situational characteristics, using $t$-tests and chi-square tests. This procedure enabled us to control the setting when that was required. A complicating factor in answering the research question was that the 181 encounters could not completely be considered as independent observations. Because of a behavioural style belonging to each nurse, it might be argued that encounters of one nurse, on average, would be more alike than those of different nurses (Hox 1995). We calculated intra-class correlation coefficients to determine this interdependency. These coefficients re ${ }^{-}$ect the proportion of total variance of an observation that is associated with the class (the nurse) to which it belongs. The magnitudes of intra-class correlations necessitated the use of a multilevel analysis. This type of analysis creates the option of 
analysing data at the level of the nurse, without disregarding the variance on the level of the nursing encounter (Hulsman 1998). Therefore correlation coefficients were computed in hierarchical linear models, using MLn software (Rasbash \& Woodhouse 1995).

\section{RESULTS}

We tested to see if the two settings differed significantly with respect to the variables under examination. No differences were found with respect to the nurses' attitudes towards elderly people, therapeutic attitude, job satisfaction or personal characteristics (Table 1). There were more male patients in home care than in the residential home (Table 2). The patients in home care were, on average, 10 years younger than patients in the old people's home $(P \leq 0.01)$. The residents in the home experienced better health than patients in the community $(P \leq$ $0.01)$. The mean duration of care was longer in the institution than in home care $(P \leq 0.05)$. Since patient characteristics seemed to be related to setting, the correlation between these characteristics and nurse communication style were calculated separately for each setting. Concerning the situational characteristics (Table 3), nurses in the old people's home had a greater number of patients during a shift than nurses in home care $(P \leq 0.01)$. Because of this distinction, correlations between situation characteristics and nurses' communication were calculated separately for each setting.

\section{[TABLE 3]}

\section{Provider variables related to nurse-patient communication}

Table 4 shows the relationships between provider variables and nurses' communication behaviour. It is primarily nurses' educational level that relates strongly to nurses' verbal and non-verbal communication. Nurses with a higher level of education less often employed social communication (personal statements, small talk and banter) than caregivers trained as auxiliary nurses. Level of education was also positively related to the amount of communication structuring the encounter (e.g. orientation and instruction, requests for clarification, and asking for understanding) and communication on nursing and health topics. The higher the level of education, the less non-verbal behaviour was used. These correlations were significant for eye gaze direction and head nodding. The education of nurses also appears to be related to the amount of irritation and dominance they show. In addition, the level of education was negatively related to the degree of involvement on the part of the nurses as perceived by observers. Nursing experience seemed to be more important in showing affective communication than the level of education. When nurses had more working experience, they showed more affective verbal communication. Another variable of interest was the attitude nurses had towards older patients. Nurses with a positive attitude had more social conversation, used more banter with their patients and used fewer verbal utterances indicating guidance and direction. Nurses who had higher intrinsic job motivation communicated more often about topics concerning nursing and health. Intrinsic work motivation was negatively related to smiling and affective touch. There was a negative correlation between satisfaction with peer contacts at work and affective verbal communication $(r=-0.24)$. A comparable relationship was found with affective touch $(r=-$ $0.34)$, meaning that the more satisfied nurses were with peer contacts the less often they showed signs of affection like empathy, concern and touch. Nurses who rated themselves high on the therapeutic attitude scale were judged as more interested by the observers. Demographic variables like age and gender of nurses seemed of minor importance in nurse communication. The two male nurses were judged to be warmer by the observers. 
Caris-Verhallen, W.M.C.M., Gruijter, I.M. de, Kerkstra, A., Bensing, J.M. Factors related to nurse communication with elderly people. Journal of Advanced Nursing: 1999, 30(5), p. 1106-1117

\section{[TABLE 4]}

\section{Patient characteristics related to nurse-patient communication}

In Table 5 the relationships are displayed between patient characteristics and nurses' communication behaviour. Since patient characteristics were related to setting, correlations for the different settings are presented separately. In home care nurses' verbal and non-verbal communication were virtually unrelated to patient characteristics. Only at the level of patients' subjective health was there a positive relation to communication about lifestyle and emotions, which means that if patients felt healthy nurses paid more attention to their lifestyle and feelings. Patient characteristics did not influence nurses' non-verbal communication. In the home for elderly people, characteristics were not related to nurses' verbal communication, which means that nurses communicated generally in the same way, irrespective of patient characteristics like age, gender or subjective state of health. This does not count for non-verbal communication: nurses nodded significantly more to patients who are older, and they leaned forward less when they cared for women. There was a strong correlation between the duration of received nursing care and the amount of instrumental touch, meaning that patients received more hygienic and technical nursing care the longer they had been in residential care.

\section{[TABLE 5]}

\section{Situation variables related to nurse-patient communication}

The relationships between situational characteristics and communication are presented in Table 6 . The correlations were calculated separately per setting. In home care, relationships occurred between the amount of hours of employment on one hand and the amount of communication that structured the encounter and instrumental touch on the other. Home care nurses taking care of more patients during a shift, talked less about nursing and health topics and more often about lifestyle and emotions. Non-verbal communication was almost unaffected by situational characteristics in home care. The only significant correlation was found between the number of patients in a shift and nurses' head nodding. In contrast with home care, in the residential home the amount of time pressure was a noticeable variable. A negative relationship existed between pressure of time and affective communication and talking about lifestyle and feelings. As nurses worked against the clock, they spent less time talking with patients about subjects, which did not directly arise from instrumental nursing tasks. As the nurse had to take care of a greater number of patients during a shift, she also used more communication that structured the encounter. The number of hours nurses worked per week was positively related to communication about lifestyle and emotions. Situation characteristics in the elderly home were shown to be of lesser importance for the non-verbal behaviours of nurses. The number of hours employed was positively related to the amount of smiling. Lastly, nurses smiled less under pressure of time.

\section{[TABLE 6]}

\section{DISCUSSION}

In the present study we examined factors that might in uence the way nurses communicate with their elderly patients. On the basis of a review of the literature (Caris- Verhallen et al. 1997a), variables related to nurses, to patients and to the setting were identified. The relation- ship of these variables to verbal and non-verbal communication was investigated.

\section{Provider characteristics}

The general conclusion on provider variables is that the amount of nursing education in particular was related to the way nurses communicated with their patients. More highly 
educated nurses showed more task-related communication such as remarks that guided the patient through the encounter and conversations about nursing and health topics, and they employed less small talk and banter with their patients. This is in accordance with Liefbroer \& Visser (1986), who found that higher level nurses provided the patient with more information about sickness and health than lower level nurses. A remarkable finding is that the level of education was negatively related to nurses' non-verbal communication, especially eye gaze direction and head nodding. A possible explanation may be that more highly educated nurses were more often engaged in technical nursing care, during which they nodded less, because their gaze was directed to the task. This explanation is supported by the finding that educational level is also related to communication about nursing and health topics. On the basis of earlier research (Armstrong-Esther et al. 1989), it was expected that nurses with favourable attitudes would pay more attention to social talk and relatively less time to task-related communication. These expectations were confirmed. Attitudes towards elderly patients (KOP scores) were positively related to social talk and negatively related to communication indicating guidance and direction. The expectation with respect to job satisfaction was not confirmed. Nurses who were satisfied with peer contacts communicated in an affective way less often. They showed less verbal attention, empathy, concern and affective touch. There is no clear explanation for these remarkable findings. It may be assumed that these nurses pay more attention to the relationship with colleagues than with patients. Demographic variables like nurses' gender and age play only a minor role in nurses' communication style. In interpreting that male nurses were judged to be warmer, we must keep in mind that only two nurses were male.

\section{Patients' characteristics}

While the literature provided some support for the ifluence of patient age, gender and level of health, our expectations about the relationship between patient characteristics and nurses' communication were not confirmed. In home care, few of the correlations between patient characteristics and nurses' communication were significant. In the home for elderly people, no significant correlations were found for verbal communication. This is in accord with the study of Brasker \& Visser (1990) who found that nurses make little allowance for the specific characteristics of elderly patients. Nevertheless, this is a curious result, meaning that nurses generally communicate in the same way, irrespective of patient characteristics like age, gender or subjective state of health. Yet, one would expect a different approach to a healthy old man from a woman of 65 who is seriously ill.

\section{Situational characteristics}

In home care, the number of patients cared for in a shift seemed to be important. A positive relation was found between the number of patients nurses had to care for and the amount of communication about lifestyle and emotions. On the other hand, the number of patients in a shift was negatively related to conversation about nursing and health topics. A possible explanation could be that nurses who are in charge of a greater number of patients are more often engaged in routine care, in which explanations of nursing and health topics is less relevant. In the literature, another variable of interest was pressure of work, which was expected to be related to the amount of nurses' social and affective communication. Both types of communication are needed to establish and maintain a relationship with the patient. In residential care the results supported this hypothesis. Experiencing time pressure may lead the nurse in the institution to ignore lifestyle and emotional topics. This is doubtful because, according to literature, there is need in elderly people to talk about their daily life and the limitations they experience with illness and growing older (Nesbitt Blondis \& Jackson 1978, Poole \& Rowat 1994). Most patients perceive their health problems as an integrated part of their existence. Task-related communication, which is only directed to the isolated health 
problem is insufficient to meet the needs in the patient and his or her environment (Pool 1996).

\section{Methodological issues}

Methodological issues concerning the observations are described in our related papers (Caris-Verhallen et al. 1997b, 1998). In this paper we confine ourselves to issues concerning the correlational design and the extent to which conclusions can be generalized.

Correlational procedures were applied because of the explorative character of the study. These techniques provide us with associations, from which we derive variables which might determine the way nurses communicate, but not causal explanations. Another restriction is imposed by the number of nurses participating in the study. Due to the limited sample of nurses it was not possible to make use of multivariate statistics, enabling us to take the interrelation among the different variables into account. A third limitation affects the extent to which generalizations can be made. The results are based on two samples in specialized settings and the nurses were not a random sample, but nurses who were going to receive training in communication skills. These limitations should be borne in mind when considering the results of the study. Still, the findings provide us with indications for interventions aiming to improve nurse-patient communication.

\section{Implications for practice}

From the preceding account it appears that time pressure, especially in the residential home, is a determinant for the verbal communication of nurses and the topics that come up for conversation. As nurses experience more time pressure they talk less about topics concerning lifestyle and emotions. This is an important point for consideration because, in nursing, high pressure is often present. One of the solutions in this area would be the establishment of more staffing. As a matter of fact this would not automatically lead to an improved quality of care. From several studies it appeared that simply employing more staff does not lead to better communication (Pool 1983, Liefbroer \& Visser 1986, Wilkinson 1991). The intervention has to be broader. In addition to a reduction in workload, the nurses should be trained to use their time efficiently. From the results it appeared that nurses' verbal communication is hardly connected to patient characteristics. Therefore in basic and continuing nursing education nurses should be trained to be sensitive to the different needs of their patients and to create an atmosphere that facilitates the patients' questions and express their needs. It is important for nurses to learn how to attune to patient needs, so that they can offer nursing care that is tailored to the individual.

\section{Acknowledgements}

This research project is financed by the Dutch Ministry of Health, Welfare \& Sports, Department for Policy on the Elderly. Special thanks to Professor Mieke Grypdonck, Department of Nursing Science, University of Utrecht, for her critical review and useful advice.

\section{REFERENCES}

Allen C.I. \& Turner P.S. (1991) The effect of an intervention programme on interactions on a continuing care ward for older people. Journal of Advanced Nursing 16, 1172-1177.

Armstrong-Esther C.A. \& Browne K.D. (1986) The in ${ }^{-}$uence of elderly patients' mental impairment on nurse-patient interaction. Journal of Advanced Nursing 11, 379-387.

Armstrong-Esther C.A., Sandilands M.L. \& Miller D. (1989) Attitudes and behaviours of nurses towards the elderly in an acute care setting. Journal of Advanced Nursing 14, 3441.

Armstrong-Esther C.A., Browne K.D. \& McAfee J.G. (1994) Elderly patients: still clean and sitting quietly. Journal of Advanced Nursing 19, 264-271.

Boumans N.P.G., Landeweerd J.A. \& Houtem J.H.M. (1989) Arbeidsvoldoening bij verpleegkundigen: Factor-en betrouwbaarheidsanalyse van een meetinstrument. (Work 
Caris-Verhallen, W.M.C.M., Gruijter, I.M. de, Kerkstra, A., Bensing, J.M. Factors related to nurse communication with elderly people. Journal of Advanced Nursing: 1999, 30(5), p. 1106-1117

satisfaction of nurses: factor analysis and reliability analysis of questionnaire.) Tijdschrift Voor Sociale Gezondheidszorg 67, 199-203.

Brasker J. \& Visser A.Ph. (1990) PatieĖntgericht gedrag van verpleegkundigen ten opzichte van oudere patieĖnten. (Patient centred behaviour of nurses in elderly nursing.) Verpleegkunde 1, 26-37.

Brown S., Gardner D.L., Perritt L. \& Kelly D.G. (1992) Improvement in attitudes toward the elderly following traditional and geriatric mock clinics for physical therapy students. Physical Therapy 72(4), 251-257.

Burgener S.C. \& Shimer R. (1993) Variables related to caregiver behaviors with cognitively impaired elders in institutional settings. Research in Nursing and Health 16, 193-202.

Caris-Verhallen W.M.C.M., Kerkstra A. \& Bensing J.M. (1997a) The role of communication in nursing care for the elderly: a review of the literature. Journal of Advanced Nursing 25, 915-933.

Caris-Verhallen W.M.C.M., De Gruijter I.M. \& Kerkstra A. (1997b) De Kwaliteit Van de Communicatie Tussen Verplegenden En Oudere ClieĖnten. (Nurse-Elderly Patient Communication and the Quality of Care.) NIVEL, Utrecht.

Caris-Verhallen W.M.C.M., Kerkstra A., Heijden P.G.M. \& van der \& Bensing J.M. (1998) Nurse-elderly patient communication in home care and institutional care: an explorative study. International Journal of Nursing Studies 35, 95-108.

Davies S.M. (1992) Consequences of division of nursing labour for elderly patients in a continuing care setting. Journal of Advanced Nursing 17, 582-589.

Davies H. \& Fallowfield L. (1991) Counselling and communication in health care: the current situation. In Counselling and Communication in Health Care (Davies H. \& Fallowfield L. eds), John Wiley \& Sons, Chichester, pp. 3-22.

Gibb H. \& O'Brien B. (1990) Jokes and reassurance are not enough: ways in which nurses relate through conversation with elderly clients. Journal of Advanced Nursing 15, 13891401.

Heintzman M., Leathers D.G., Parrott R.L. \& Cairns A.B. III (1993) Non-verbal rapportbuilding behaviors' effect on perceptions of a supervisor. Management Communication Quarterly 7(2), 181-208.

Hockey L. (1976) Woman in Nursing. Hodder \& Stoughton, London.

Hope K.W. (1994) Nurses' attitudes towards older people: a comparison between nurses working in acute medical and acute care of elderly patients settings. Journal of Advanced Nursing 20, 605-612.

Hox I.J. (1995) Applied Multilevel Analysis 2nd edn. TT Publications, Amsterdam.

Hulsman R.L. (1998) Communication Skills of Medical Specialists in Oncology: Development and Evaluation of a Computer Assisted Instruction Program. NIVEL, Utrecht.

Iec ProGAMMA (1994) User Manual CAMERA: A System for Collecting and Correcting Behavioral Data. lec ProGAMMA, Groningen.

Kogan N. (1961) Attitudes towards old people, the development of a scale an examination of correlates. Journal of Abnormal and Social Psychology 62, 44-54.

Kramer K. \& Kerkstra A. (1991) Eenzaamheid Van Bewoners in Een Verzorgingstehuis. (Loneliness of Residents in an Elderly Home.) NIVEL, Utrecht.

Lane P.L. (1989) Nurse-client perceptions: the double standard of touch. Issues in Mental Health Nursing 10, 1-13.

Ley P. (1988) Communicating with Patients, 2nd edn. Chapman \& Hall, London.

Liefbroer A.C. \& Visser A.Ph. (1986) Meten en determinanten van het patieĖntgericht gedrag van verpleegkundigen. (Determinants of patient centred behaviour in nurses.) Gezondheid En Samenleving 7, 154-162.

Lookinland S. \& Anson K. (1995) Perpetuation of ageist attitudes among present and future health care personnel: implications for elder care. Journal of Advanced Nursing 21, 47-56.

Macleod Clark J. (1985) The development of research in interpersonal skills in nursing. In Interpersonal Skills in Nursing (Kagan C. ed.), Croom Helm, Dover, New Hampshire, pp. 921.

Nesbitt Blondis M. \& Jackson B.E. (1978) Zonder Woorden: Nonverbale Communicatie Met PatieĖnten. (Without Words: Non-Verbal Communication with Patients.) De toorts, Haarlem. 
Caris-Verhallen, W.M.C.M., Gruijter, I.M. de, Kerkstra, A., Bensing, J.M. Factors related to nurse communication with elderly people. Journal of Advanced Nursing: 1999, 30(5), p. 1106-1117

Penninx K. (1995) Beeldvorming Over Ouder Worden. (Images about Growing Older.) Bohn Stafleu Van Loghum, Houten.

Pool J.J. (1983) Sociaal Therapeutisch Gedrag Van Verpleegkundigen: Verslag Van Onderzoek En Interventie.

(Socio Therapeutic Behaviour in Nursing: Report of Research and Intervention.) VU Boekhandel en Uitgeverij, Amsterdam.

Pool A. (1996) Zeggenschap in zorgplannen: een communicatieprobleem? (Control in care planning: a communication problem?) In Zorgen \& Communiceren (Care \& Communication) (Boon L. ed.), Stichting Sympoz, Amstelveen, pp. 97-102.

Poole G.\&Rowat K. (1994) Elderly clients' perceptions of caring of a home-care nurse. Journal of Advanced Nursing 20, 422-429.

Rasbash J. \& Woodhouse G. (1995) MLn Command Reference, Version 1.0. Multilevel Models Project. Institute of Education, University of London, London.

Roter D. (1989) The Roter Method of Interaction Process Analysis. Johns Hopkins University Press, Baltimore.

Ruijters R.F.M. \& Stevens F.C.J. (1992) Organisatiestructuur, rolduidelijkheid, arbeidssatisfactie en het oordeel van verpleegkundigen over de samenwerking met artsen. (Organizational structure, role clarity, job satisfaction and nurses' assessment on cooperation with doctors.) Verpleegkunde 2, 106-114.

Salmon P. (1993) Interactions of nurses with elderly patients: relationship to nurses' attitudes and to formal activity periods. Journal of Advanced Nursing 18, 14-19.

Smith S.P. (1982) Attitudes of nursing care providers toward elderly patients. Nursing and Health Care 3, 93-98.

Taft L.B. (1985) Self esteem in later life: a nursing perspective. Advances in Nursing science 51(1), 77-84.

Tempelman C.J.J. (1987) Welbevinden Bij Ouderen: Konstruktie Van Een Meetinstrument. (Well-Being in the Elderly: Construction of a Questionnaire.) Rijksuniversiteit, Groningen.

Thomas L.H. (1994) A comparison of the verbal interactions of qualified nurses and nursing auxiliaries in primary, team and functional nursing wards. International Journal of Nursing Studies 31(3), 231-244.

Thomas L.H. \& Bond S. (1990) Towards defining the organization of nursing care in hospital wards: an empirical study. Journal of Advanced Nursing 15, 1106-1112.

Treharne G. (1990) Attitudes towards the care of elderly people: are they getting better? Journal of Advanced Nursing 15, 777-781.

Turner P. (1993) Activity nursing and the changes in the quality of life of elderly patients; a semi-quantitative study. Journal of Advanced Nursing 18, 1727-1733.

Van Cott M.L. (1993) Communicative competence during nursing admission interviews of elderly patients in acute care settings. Qualitative Health Research 3(2), 184-208.

Visser A.Ph. (1988) De meting van tevredenheid van ziekenhuispatieĖnten: ontwikkeling en betekenis van een vragenlijst. (PatieĖnt satisfaction in hospital: development and meaning of a questionnaire.) In Onderzoek naar de tevredenheid van ziekenhuispatieĖnten: doel methode en beleid (Satisfaction Research in Hospital Patients: Aim, Methods and Policy) (Visser A.Ph. ed.), de Tijdstroom, Lochem, pp. 25-51.

de Wilde I. \& de Bot K. (1989) Taal van verzorgenden tegen ouderen in een psychogeriatrisch verpleeghuis. (Language in nursing the elderly in a psycho-geriatric nursing home.) Tijdschrift Voor Gerontologie En Geriatrie 20, 97-100.

Wilkinson S. (1991) Factors which in ${ }^{-}$uence how nurses communicate with cancer patients. Journal of Advanced Nursing 16, 677-688. 
Caris-Verhallen, W.M.C.M., Gruijter, I.M. de, Kerkstra, A., Bensing, J.M. Factors related to nurse communication with elderly people. Journal of Advanced Nursing: 1999, 30(5), p. 1106-1117

\section{TABLES}

Table 1 Distribution of different characteristics of nurses participating in the study $(n=47)$

\begin{tabular}{|c|c|c|c|c|}
\hline \multirow[t]{2}{*}{ Provider variables } & \multicolumn{2}{|c|}{ Community $(n=24)$} & \multicolumn{2}{|c|}{ Residential hame ( $n=23)$} \\
\hline & mean & (SD) & mean & (SD) \\
\hline \multicolumn{5}{|l|}{ Attitude } \\
\hline Attitude towards the elderly & $4 \cdot 0$ & $(0-3)$ & $4 \cdot 1$ & $(0-4)$ \\
\hline Patient-directed attitude & $3 \cdot 7$ & $(0-3)$ & 3.5 & $(0.5)$ \\
\hline \multicolumn{5}{|l|}{ Job satisfaction ${ }^{2}$} \\
\hline Instrinsic job motivation & $3 \cdot 8$ & $(0-4)$ & $3 \cdot 7$ & $(0 \cdot 5)$ \\
\hline Satisfaction with colleagues & $4 \cdot 0$ & $(0-4)$ & $4 \cdot 0$ & $(0-6)$ \\
\hline \multicolumn{5}{|l|}{$\begin{array}{l}\text { Demographic characteristics } \\
\text { Gender }\end{array}$} \\
\hline Women & $100 \%$ & & $91 \%$ & \\
\hline Men & & & $9 \%$ & \\
\hline Mean age & $37 \cdot 4$ & $(9 \cdot 3)$ & $40 \cdot 9$ & $(8 \cdot 7)$ \\
\hline \multicolumn{5}{|l|}{ Educational level $1^{1, b}$} \\
\hline Nurses & $46 \%$ & & $35 \%$ & \\
\hline Auxiliary nurses & $54 \%$ & & $65 \%$ & \\
\hline Years of employment & $16 \cdot 5$ & $(8 \cdot 8)$ & $15 \cdot 9$ & $(7 \cdot 2)$ \\
\hline
\end{tabular}

${ }^{1}$ Nurses=Dutch higher professional education level (HBO or 3.5 years of in-service education). Auxiliary Nurses=Dutch secondary professional education level (MBO or 2.5 years of in-service education).

a Difference in attitudes, job satisfaction, age and amount of experience were tested by means of $t$-tests.

${ }^{b}$ Difference in gender and education level were tested by means of a chi-square test.

Table 2 Distribution of patient characteristics in home care and the residential home $(n=109)$

\begin{tabular}{|c|c|c|c|c|}
\hline \multirow[b]{2}{*}{ Patient characteristics } & \multicolumn{2}{|c|}{$\begin{array}{l}\text { Community } \\
(n=101)\end{array}$} & \multicolumn{2}{|c|}{$\begin{array}{l}\text { Residential home } \\
(n=28)\end{array}$} \\
\hline & Mean & (SD) & Mean & (SD) \\
\hline \multicolumn{5}{|l|}{ Gender $^{b}$} \\
\hline Wamen & $65 \%$ & & $89 \%$ & \\
\hline Men & $35 \%$ & & $11 \%$ & \\
\hline Mean age ${ }^{a}$ & $77 \cdot 5$ & $(8 \cdot 7)^{* *}$ & $86 \cdot 7$ & $(4 \cdot 4)$ \\
\hline Subjective health ${ }^{a}$ & $2 \cdot 0$ & $(0-4)^{* *}$ & $2 \cdot 3$ & $(0-4)$ \\
\hline $\begin{array}{l}\text { Mean duration of received } \\
\text { nursing care in months }{ }^{2}\end{array}$ & 37 & $(436)^{*}$ & 70 & $(77 \cdot 2)$ \\
\hline
\end{tabular}

"Differences in age, subjective health and mean duration of received nursing care were tested by means of $t$-tests.

${ }^{b}$ Differences in gender were tested by means of a chi-square test.

* Significance level of $P \leq 0-5$.

* Significance level of $P \leq 0.01$. 
Caris-Verhallen, W.M.C.M., Gruijter, I.M. de, Kerkstra, A., Bensing, J.M. Factors related to nurse communication with elderly people. Journal of Advanced Nursing: 1999, 30(5), p. 1106-1117

Table 3 Distribution of situation characteristics $(n=47)$

\begin{tabular}{|c|c|c|c|c|}
\hline \multirow[b]{2}{*}{ Situation variables } & \multicolumn{2}{|c|}{$\begin{array}{l}\text { Home care } \\
(n=24)\end{array}$} & \multicolumn{2}{|c|}{$\begin{array}{l}\text { Residential } \\
\text { home }(n=23)\end{array}$} \\
\hline & Mean & (SD) & Mean & (SD) \\
\hline Time pressure & $2 \cdot 5$ & $(0-7)$ & $2 \cdot 7$ & $(1.0)$ \\
\hline $\begin{array}{l}\text { Number of patients during } \\
\text { a shift }\end{array}$ & $7 \cdot 2$ & $(1 \cdot 1)^{*}$ & $11 \cdot 4$ & $(5 \cdot 5)$ \\
\hline Hours of employment a week & $28 \cdot 0$ & $(6 \cdot 1)$ & $25 \cdot 1$ & $(10-0)$ \\
\hline
\end{tabular}

* Significance level of $P \leq 0.01$.

Table 4 Overview carrelations between provider variables and verbal and non-verbal communication $(n=47 \text { nurses })^{1}$

\begin{tabular}{|c|c|c|c|c|c|c|c|c|}
\hline & Age & Gender & Education & $\begin{array}{l}\text { Years } \\
\text { of } \\
\text { employment }\end{array}$ & $\begin{array}{l}\text { Attitude } \\
\text { towards } \\
\text { elderly people }\end{array}$ & $\begin{array}{l}\text { Intrinsic } \\
\text { work } \\
\text { motivation }\end{array}$ & $\begin{array}{l}\text { Satisfaction } \\
\text { with } \\
\text { colleagues }\end{array}$ & $\begin{array}{l}\text { Therapeutic } \\
\text { attitude }\end{array}$ \\
\hline \multicolumn{9}{|l|}{ Verbal communication } \\
\hline $\begin{array}{l}\text { Social conversation } \\
\text { and jokes }\end{array}$ & 0.06 & $-0 \cdot 06$ & $-0035 * *$ & -0.04 & $0 \cdot 25^{*}$ & $-0 \cdot 15$ & 0.08 & $-0 \cdot 17$ \\
\hline Affective communication & $0 \cdot 22$ & 0.01 & $0 \cdot 15$ & $0.39 * *$ & 0.11 & -0.09 & $-0 \cdot 24^{*}$ & $0 \cdot 18$ \\
\hline $\begin{array}{l}\text { Communication that } \\
\text { structures the encounter }\end{array}$ & $-0 \cdot 10$ & $-0 \cdot 20$ & $0 \cdot 30^{*}$ & $-0 \cdot 12$ & $-0.32^{*}$ & 0.09 & $-0 \cdot 01$ & -0.04 \\
\hline $\begin{array}{l}\text { Communication about } \\
\text { nursing and health }\end{array}$ & $-0 \cdot 11$ & $0 \cdot 21$ & $0.28^{*}$ & -0.09 & $-0 \cdot 17$ & $0.27^{*}$ & 0.06 & 0.07 \\
\hline $\begin{array}{l}\text { Communication about } \\
\text { lifestyle and emotions }\end{array}$ & $-0 \cdot 10$ & 0.01 & $-0 \cdot 10$ & $-0 \cdot 10$ & -0.05 & -0.04 & 0.03 & 0.09 \\
\hline \multicolumn{9}{|l|}{ Non-verbal communication } \\
\hline Eye gaze direction & $-0 \cdot 12$ & 0.06 & $-0.33^{*}$ & $-0 \cdot 13$ & 0.08 & 0.01 & 0.00 & 0.04 \\
\hline Forward leaning & $0 \cdot 11$ & $0 \cdot 21$ & -0.07 & -0.05 & $-0 \cdot 07$ & $-0 \cdot 15$ & $-0 \cdot 10$ & -0.15 \\
\hline Head nodding & $-0 \cdot 06$ & $0 \cdot 12$ & $-0.24^{*}$ & 0.09 & $0 \cdot 15$ & $-0 \cdot 01$ & $0 \cdot 12$ & $-0-03$ \\
\hline Smiling & $0.29^{*}$ & 0.02 & -0.08 & $0 \cdot 17$ & 0.14 & $-0.27^{*}$ & -0.10 & $0 \cdot 12$ \\
\hline Affective touch & $0 \cdot 19$ & -0.07 & $-0 \cdot 13$ & $-0 \cdot 22$ & 0.07 & $-0.26^{*}$ & $-0.34^{* *}$ & 0.06 \\
\hline Instrumental touch & -0.06 & $-0 \cdot 15$ & $0 \cdot 11$ & $0-01$ & -0.06 & $-0 \cdot 04$ & $0 \cdot 22$ & $-0-05$ \\
\hline \multicolumn{9}{|l|}{ Global affect ratings } \\
\hline Anger/irritation & $-0 \cdot 13$ & 0.06 & $0.26^{*}$ & -0.08 & $-0 \cdot 12$ & 0.09 & 0.7 & $0 \cdot 10$ \\
\hline Nervousness & $-0 \cdot 01$ & 0.07 & -06 & 0.05 & 0.05 & $0 \cdot 10$ & $-0 \cdot 20$ & -0.05 \\
\hline Dominance & 0.21 & $0 \cdot 19$ & $0 \cdot 38^{* *}$ & $0 \cdot 10$ & $-0 \cdot 04$ & $-0 \cdot 06$ & -0.05 & 003 \\
\hline Interest & 0.01 & -0.03 & -0.09 & -0.06 & 0.20 & 0.00 & 0.09 & $0.27^{*}$ \\
\hline Warmth & 0.05 & $-0 \cdot 30^{*}$ & -0.04 & -0.01 & 0.23 & -0.02 & 0.02 & $0 \cdot 21$ \\
\hline Patronizing & 0.06 & 005 & $0 \cdot 21$ & $0 \cdot 17$ & -0.06 & $0 \cdot 00$ & -0.04 & $-0 \cdot 10$ \\
\hline Involved attitude & $0 \cdot 11$ & $-0 \cdot 17$ & $-0.26^{*}$ & 0.05 & 0.10 & $-0 \cdot 12$ & $-0 \cdot 14$ & $0 \cdot 17$ \\
\hline
\end{tabular}

${ }^{1}$ The observation variables were aggregated to the level of the nurse.

$* P \leq 005$ (1-tailed significance).

$* P \leq 001$ 
Caris-Verhallen, W.M.C.M., Gruijter, I.M. de, Kerkstra, A., Bensing, J.M. Factors related to nurse communication with elderly people. Journal of Advanced Nursing: 1999, 30(5), p. 1106-1117

Table 5 Overview carrelations between patient variables and nurses verbal and non-verbal communication $\left(n=109\right.$ patients) ${ }^{1}$

\begin{tabular}{|c|c|c|c|c|c|c|c|c|}
\hline & \multicolumn{4}{|c|}{ Community } & \multicolumn{4}{|c|}{ Residential home } \\
\hline & Gender & Age & $\begin{array}{l}\text { Subjective } \\
\text { state of } \\
\text { health }\end{array}$ & $\begin{array}{l}\text { Duration of } \\
\text { received } \\
\text { nursing care }\end{array}$ & Gender & Age & $\begin{array}{l}\text { Subjective } \\
\text { state of } \\
\text { health }\end{array}$ & $\begin{array}{l}\text { Duration of } \\
\text { received } \\
\text { nursing care }\end{array}$ \\
\hline \multicolumn{9}{|l|}{ Verbal communication } \\
\hline Social conversation and jokes & 0.06 & $0 \cdot 10$ & 0.04 & $0 \cdot 13$ & $-0 \cdot 08$ & $-0 \cdot 19$ & -0.08 & $-0 \cdot 13$ \\
\hline Affective communication & -0.04 & -0.03 & $-0 \cdot 13$ & $-0 \cdot 17$ & $-0 \cdot 14$ & $0 \cdot 10$ & $0 \cdot 14$ & -0.07 \\
\hline $\begin{array}{l}\text { Cammunication that } \\
\text { structures the encounter }\end{array}$ & 001 & 0.01 & -0.05 & 0.08 & $0 \cdot 07$ & $0 \cdot 16$ & $-0 \cdot 15$ & $0 \cdot 12$ \\
\hline $\begin{array}{l}\text { Communication about } \\
\text { nursing and health }\end{array}$ & -0.07 & -0.09 & -0.07 & -0.01 & 0.09 & $0 \cdot 13$ & $-0 \cdot 10$ & $0 \cdot 19$ \\
\hline $\begin{array}{l}\text { Cammunication about } \\
\text { lifestyle and emotions }\end{array}$ & -0.01 & -0.03 & $0 \cdot 23^{*}$ & -0.07 & $0 \cdot 20$ & $-0 \cdot 04$ & $0 \cdot 30$ & 0.01 \\
\hline \multicolumn{9}{|l|}{ Non-verbal communication } \\
\hline Eye gaze direction & 001 & 0.09 & -0.05 & $-0 \cdot 13$ & $-0 \cdot 14$ & $0 \cdot 20$ & $0 \cdot 29$ & $-0 \cdot 16$ \\
\hline Forward leaning & 002 & $0 \cdot 15$ & $0 \cdot 17$ & 0.00 & $-0 \cdot 45^{* *}$ & $-0 \cdot 29$ & $-0 \cdot 24$ & $0 \cdot 12$ \\
\hline Head nodding & 0.08 & $0 \cdot 15$ & 0.04 & -0.07 & $-0-03$ & $0.45^{* *}$ & $0 \cdot 14$ & $-0 \cdot 20$ \\
\hline Smiling & 005 & $0 \cdot 15$ & 021 & -0.04 & $0-06$ & $0 \cdot 17$ & $-0 \cdot 15$ & $-0 \cdot 11$ \\
\hline Affective touch & $0 \cdot 16$ & $0 \cdot 11$ & $-0 \cdot 11$ & -0.07 & $-0-18$ & $0-21$ & $-0 \cdot 27$ & $0 \cdot 13$ \\
\hline Instrumental touch & $-0 \cdot 10$ & 0.00 & 0.02 & $0 \cdot 15$ & $0-04$ & $-0 \cdot 19$ & $0 \cdot 24$ & $069 * *$ \\
\hline
\end{tabular}

${ }^{1}$ The observation variables were aggregated to the level of the patient.

* $P=\leq 0.05$ (1-tailed significance).

$* P=\leq 001$.

$* P=\leq 0001$.

Table 6 Overview carrelations between situation variables and nurses verbal and non-verbal communication $\left(n=47\right.$ nurses) ${ }^{1}$

\begin{tabular}{|c|c|c|c|c|c|c|}
\hline & \multicolumn{3}{|l|}{ Community } & \multicolumn{3}{|c|}{ Residential home } \\
\hline & $\begin{array}{l}\text { Hours of } \\
\text { employment }\end{array}$ & $\begin{array}{l}\text { Number of } \\
\text { patients in } \\
\text { a shift }\end{array}$ & $\begin{array}{l}\text { Pressure } \\
\text { of time }\end{array}$ & $\begin{array}{l}\text { Hours of } \\
\text { employment }\end{array}$ & $\begin{array}{l}\text { Number of } \\
\text { patients in } \\
\text { a shift }\end{array}$ & $\begin{array}{l}\text { Pressure } \\
\text { of time }\end{array}$ \\
\hline \multicolumn{7}{|l|}{ Verbal communication } \\
\hline Social conversation and jokes & $-0 \cdot 16$ & $-0 \cdot 30$ & -0.06 & $-0 \cdot 17$ & $-0 \cdot 15$ & 0.29 \\
\hline Affective communication & $-0 \cdot 24$ & $0 \cdot 12$ & $-0 \cdot 13$ & $0 \cdot 11$ & -0.01 & $-0.41^{*}$ \\
\hline $\begin{array}{l}\text { Communication that structures } \\
\text { the encounter }\end{array}$ & $0.39^{*}$ & 0.07 & $0 \cdot 17$ & $0 \cdot 11$ & $0.40^{*}$ & $-0 \cdot 16$ \\
\hline Communication about nursing and health & $0 \cdot 25$ & $-0 \cdot 34^{*}$ & $0 \cdot 18$ & $-0 \cdot 18$ & -0.26 & $0 \cdot 20$ \\
\hline $\begin{array}{l}\text { Cammunication about lifestyle } \\
\text { and emotions }\end{array}$ & $-0 \cdot 13$ & $0 \cdot 59 * *$ & $-0 \cdot 16$ & $0 \cdot 39^{*}$ & $0 \cdot 04$ & $-0 \cdot 39^{*}$ \\
\hline \multicolumn{7}{|l|}{ Non-verbal communication } \\
\hline Eye gaze direction & $-0 \cdot 11$ & $0 \cdot 33$ & -009 & $0 \cdot 14$ & $0 \cdot 22$ & $-0 \cdot 21$ \\
\hline Forward leaning & $-0 \cdot 33$ & $-0 \cdot 12$ & 0.08 & $-0 \cdot 11$ & $0 \cdot 22$ & $-0 \cdot 23$ \\
\hline Head nodding & $-0 \cdot 25$ & $045 * *$ & $-0 \cdot 11$ & -0.03 & $0 \cdot 10$ & $-0 \cdot 29$ \\
\hline Smiling & -0.27 & $-0 \cdot 32$ & $-0 \cdot 10$ & $0.39^{*}$ & $-0 \cdot 02$ & $-0.37^{*}$ \\
\hline Affective touch & $0 \cdot 08$ & $-0 \cdot 12$ & $0 \cdot 33$ & 0.19 & -0.05 & $-0 \cdot 17$ \\
\hline Instrumental touch & $0.42^{*}$ & $-0 \cdot 21$ & $0 \cdot 17$ & 0.04 & $-0 \cdot 08$ & $0-11$ \\
\hline
\end{tabular}

${ }^{1}$ The observation variables were aggregated to the level of the nurse.

* $P \leq 005$ (1-tailed significance).

$* P \leq 0.01$.

$\cdots P \leq 0001$ 